\title{
Aggressive Tax Planning and Corporate Tax Avoidance: The Case Study
}

\author{
Adzhar Sulaiman, Kamil Md. Idris and Saliza Abdul Aziz* \\ Tunku Puteri Intan Safinaz School of Accountancy, Universiti Utara Malaysia
}

\begin{abstract}
There have been increasing literature on aggressive tax planning and corporate tax avoidance, which focus on economic consequences (Ksovreli, 2015; Hanlon \& Heitzman, 2010). Campaigners have targeted tax-avoiding corporations through the media, citing the enormous amount of tax losses (Hasseldine, Holland \& Van der Rijt, 2012). It is pertinent that policy-makers and tax authorities to take action against tax avoiders and tax intermediaries. This paper focuses on the tax avoidance structures identified during tax audits and investigations and further contributes to an understanding of tax avoidance structures and models. The key models identified are related to the abuse of tax incentives and the use of corporate restructuring to minimize or reduced tax exposures. Based on the Case Management System of the Inland Revenue Board of Malaysia, we identify the key structures, their roles and incentives, and outline the tax avoidance schemes. The study summarizes a range of policy responses to tax avoidance, including anti-avoidance rules, disclosure rules and the regulation of tax intermediaries such as tax practitioners.
\end{abstract}

Keywords: Tax avoidance, corporate restructuring, tax intermediaries

JEL Classification: $\mathrm{H} 26$

Paper Type: Research

\section{INTRODUCTION}

The global economic crisis involving multinationals and large corporations with regards to corporate tax planning and tax avoidance has attracted international interest (Lisowsky, 2010; Hanlon \& Heitzman, 2010). The concentration on tax avoidance 
'schemes', which is frequently prefaced as offensive, intolerable and 'unacceptable' has attracted attention from various parties - campaigners, tax authorities and the OECD (OECD, 2017). Tax havens and profit shifting in 'aggressive' tax planning is the main concern to governments (OECD, 2017). The governments, in their effort to promote investments, must evaluate the viability and impact to the economy and financial revenue in their quest to create 'business friendly' tax environment. This policy has created opportunities for multinational corporations (MNCs) and domestic firms to exploit the loopholes and avoid paying taxes. Proper evaluation of such policies must be carried out to protect and maintain their tax base. Granting tax holidays or reduced tax rates should be carefully evaluated and monitored.

Tax havens offering attractive tax rates and financial secrecy have been the primary targets as a conduit in tax avoidance schemes. Many countries are losing billions of dollars through tax avoidance using tax havens. The estimated global tax losses is about $\$ 500$ billion a year which is about $4 \%$ to $6 \%$ of corporate tax revenue (Cobham \& Jansky, 2018; Turner, 2017) The amount revenue loss among OECD countries is estimated about 2 to $3 \%$ of their total tax revenues while developing countries within the range of $6 \%$ to $13 \%$ (Cobham \& Jansky, 2018; Turner, 2017). Similarly, governments have been willing to forgo a substantial amount of tax revenues when offering tax incentives in their effort to attract foreign direct investments. Regionally, countries tend to compete with each other, thus creating unfair competition to the domestic businesses in their 'race to the bottom' (Zolt, 2016).

The massive inflows of funds have made offshore tax havens as 'global financial centres'. For example, Mauritius, a sub-Saharan African country has attracted megacorporations fund managers with Goldman Sachs leading with 49 subsidiaries, followed by JP Morgan Chase (33 subsidiaries), Morgan Stanley (16 subsidiaries), Citigroup (5 subsidiaries), and Pepsi (2 subsidiaries) respectively. Mauritius has also drawn more than 32,000 offshore business units, primarily targeting business ventures in India, South Africa, and China ("Mauritius Economy 2018", 2018). Mauritius was also the largest foreign investor into India at $25 \%$ of total foreign investments in India for the year 2010 ("Mauritius Economy 2018", 2018). These phenomena do not make sense as the funds are coming from countries with small economies.

Other tax havens such as the British Virgin Islands, Barbados and Bermuda have received more direct investment than Japan and Germany in the year 2010. British Virgin Islands investment in China accounted for $14 \%$ of total foreign investments and was the second largest investor in China in 2010. Hong Kong was the largest investor at $45 \%$, and the United States(US) was way behind at only 4\% (Cobham \& Jansky, 2018; Turner, 2017). The OECD and International Monetary Fund believed that these funds are then rerouted for further investments into other countries. It does not make sense countries with small GDP and lack of economic substance pumping huge amounts of funds into countries with mature economies. For example, the largest foreign investor in Russia is Cyprus, which is about 25\% of all foreign investments into Russia in 2010 (Cobham \& Jansky, 2018).

We often conjure that tax havens are isolated islands where billions of dollars are hoarded under cover of secrecy. However, in reality, most of the most significant players in tax avoidance and financial concealment are nearer than we think. The Tax Justice Network rates Switzerland as the front runner for tax avoidance and financial secrecy. The US is ranked third while Germany and Luxembourg fall in the top 10. It is easier to hide monies in the US than other known tax havens (Kasperkevic, 2016). There are large offshore centres residing in the US states such as Nevada, Delaware, Montana, South Dakota, Wyoming and New York where the state legislation allows individuals and companies to have the benefit of tax-free wealth (Swanson, 2016; Vicentes, 2017). 
Shockingly, Bermuda, the small island at the centre of controversy exposed in the Paradise Papers is ranked 34th in terms of financial secrecy. More expressively, United Kingdom (UK) (15th) and Canada (29th) rank well above Bermuda. None of the small islands often associated being a tax haven is within the top 10 except for the Cayman Islands, which is ranked fifth.

Most studies on tax avoidance and aggressive tax planning revolve around tax havens. All the controversies concerning tax haven countries, especially about closing down tax havens, and financial secrecy should also include members of the G20 countries and not just the small islands. However, countries like Ireland, Germany and Netherlands are rarely regarded as tax havens even though hoarding billion in assets which simply implies countries like Canada, US and some EU member states are advocating for a tax-haven double standard. The fact that tax avoidance and tax planning are within the corridors should justify that the domestic laws need to be reviewed, and policy changes are needed to combat tax avoidance. As countries with tax incentives regimes offer similar advantages offered by tax havens countries, they are vulnerable to abuse (Zolt, 2016). Tax incentives regimes are similar in many ways to tax havens and becoming targets as enablers of tax avoidance, tax evasion and money laundering as in the case of Starbucks, Apple Inc. and Google Inc. exploiting the preferential tax rates offered by Ireland, Switzerland and the Netherlands.

In this paper, prior research on tax avoidance and tax planning as well as documented cases solved by the Inland Revenue Board of Malaysia (IRBM) involving tax incentives are referred. Many companies have successfully implemented their tax planning strategies while some 'overstepped' the boundaries on being too aggressive; thus, being caught by the tax authorities. The study contribution is to conceptualize tax avoidance schemes and identify the enablers of tax avoidance schemes. Particularly, tax avoidance schemes involving corporate restructuring and rent-seeking where taxpayers take full advantage of the incentives offered; however, in the course of restructuring certain transactions violates the law. This study also documents the types of tax avoidance schemes identified involving corporate restructuring.

The Inland Revenue Board of Malaysia (IRBM) have identified the users of corporate restructuring involving tax incentives in tax planning schemes. The IRBM has risen more than RM2 billion in 2017 involving corporate restructuring and manipulation of tax incentives. Manipulations involving tax incentives through the creation of shell companies and claims involving non-qualifying expenditures have created more than RM48 billions of non-taxable income for the year 2013-2016 as reported in the IRBM Report in the year 2017.

\section{LITERATURE REVIEW}

Countries adopted a tax system in congruence with national needs. The difference in tax policies, legislation and rates create opportunities for companies to reduce their tax exposure by 'shifting' income across jurisdictions. For decades, multinational companies have legally shift profits from high tax regimes to lower tax regimes. Further, the difference in domestic law and international tax law has created many 'loopholes' in the tax legislation (VanDenburgh, 2012; Yang \& Montello, 2018). Many multinational corporations (MNCs) have exploited these loopholes to their advantage in sheltering their income from being taxed. The European Commission (2016) had inflicted an enormous \$16 billion in penalties on Apple Inc., USA, when Apple Inc. was accused of exploiting the loopholes, gaining an unfair advantage through "illegal tax subsidies" from the Irish government. This decision shocked the investment community worldwide. The 
tax loopholes abuses have become severe that countries must take measures to address these issues (Arukesamy, 2018).

Morgan (2016) argued that the difference in tax legislation between countries is one of the root causes of international tax avoidance, where profits are not declared or reported where they are created. The changes in the world economy where MNCs derived profits from different parts of the world made it difficult to determine its origin, thus making it almost impossible to tax these profits (Morgan, 2016). Further, the current legislation has been unable to cope with the changes in the business environment (Morgan, 2016; Olbert \& Spengel, 2017). This creates loopholes that could provide opportunities for MNCs to treaty shopping or rent-seeking to exploit the weakness of the tax legislation either through corporate restructuring or corporate re-location where reporting of sales, revenue and profits are manipulated (Arel-Bundock, 2017). This simply means that the current tax laws and tax treaties are obsolete (Morgan, 2016). Therefore, major tax reform is necessary, and governments must take action to update tax legislation to address this problem. Further, there are also significant differences in tax legislation between countries.

The common methods in tax avoidance are profit-shifting, rent-seeking and treaty shopping (OECD, 2017). Countries with low tax rates and offering other tax incentives are vulnerable to abuse in tax avoidance schemes. Many US corporations have relocated their businesses to Europe to take advantage of the low tax rates and preferential treatments. The "Luxembourg leaks" (Lux Leaks) exposed that many tax rulings were issued between tax authorities and MNCs that effectively reduced their tax exposure ("Leaked Documents Expose Global Companies' Secret Tax Deals in Luxembourg", 2014). The tax authorities issued special tax rulings that falsely reduced the tax exposure by the relevant companies. Apple Inc. and Starbucks are among the MNCs that benefited from these rulings.

\section{Case 1: Apple, Inc.}

Apple Inc. The US established a subsidiary in Ireland to take advantage of Ireland's low tax rates. The Ireland subsidiary was used as a conduit to transfer profits from other subsidiaries in Europe, thus reducing Apple's tax liability (Drozdiak \& Schechner, 2016). Apple was granted low tax rates by tax rulings issued by Ireland. Apple only pays tax at a special rate of $1 \%$ or less as compared to the normal rate of $12.5 \%$. Apple exploited this low tax advantage by shifting profits from subsidiaries in Europe to Ireland, where the contract of sales signs between Apple Ireland, not the corresponding European outlets. The European Commission (2016) concluded that Ireland granted special tax advantages to Apple, thus giving Apple an unfair competitive advantage over other businesses operating within its boundaries. In other words, Ireland sanctioned Apple to shift profits, which did not reflect the real economic activity where virtually all profits were attributed to a "head office." It was established that these "head offices" are shell companies which existed only on paper and it is impossible to justify a large number of profits generated by these head offices. The biggest irony is that these profits are not taxed in any country. Ireland was ordered to recover the tax losses for the years 2003 to 2014, amounting to $\$ 16$ billion plus interest, from Apple. To surmise, Apple was avoiding tax mainly due to its Irish-based tax structure, which includes three 'stateless' Irish subsidiaries that were not taxable in any country. 


\section{Apple's Offshore Organizational Structure}

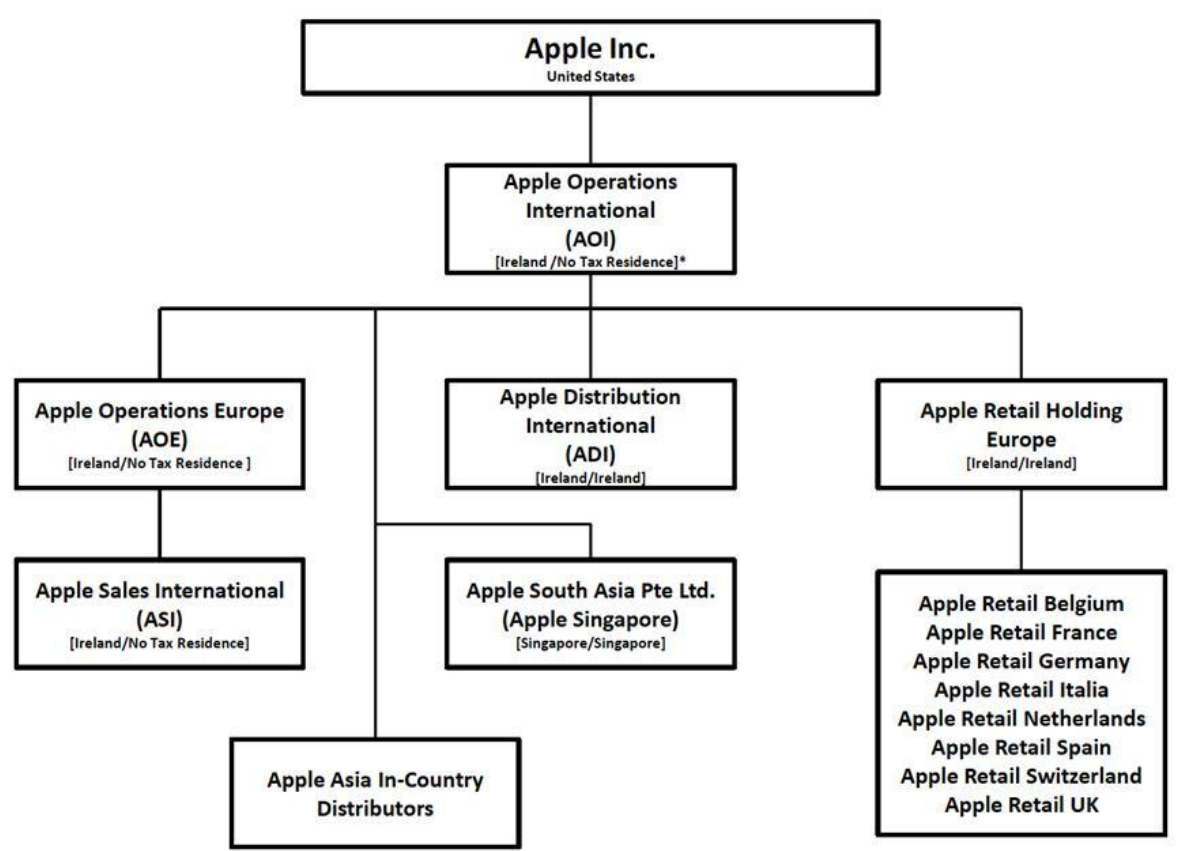

"Listed countries indicate country of incorporation and country of tax residence, respectively.

Prepared by the Permanent Subcommittee on Investigations, May 2013. Source: Materials received from Apple Inc.

Figure 1. Ireland gave illegal preferential tax treatment to Apple

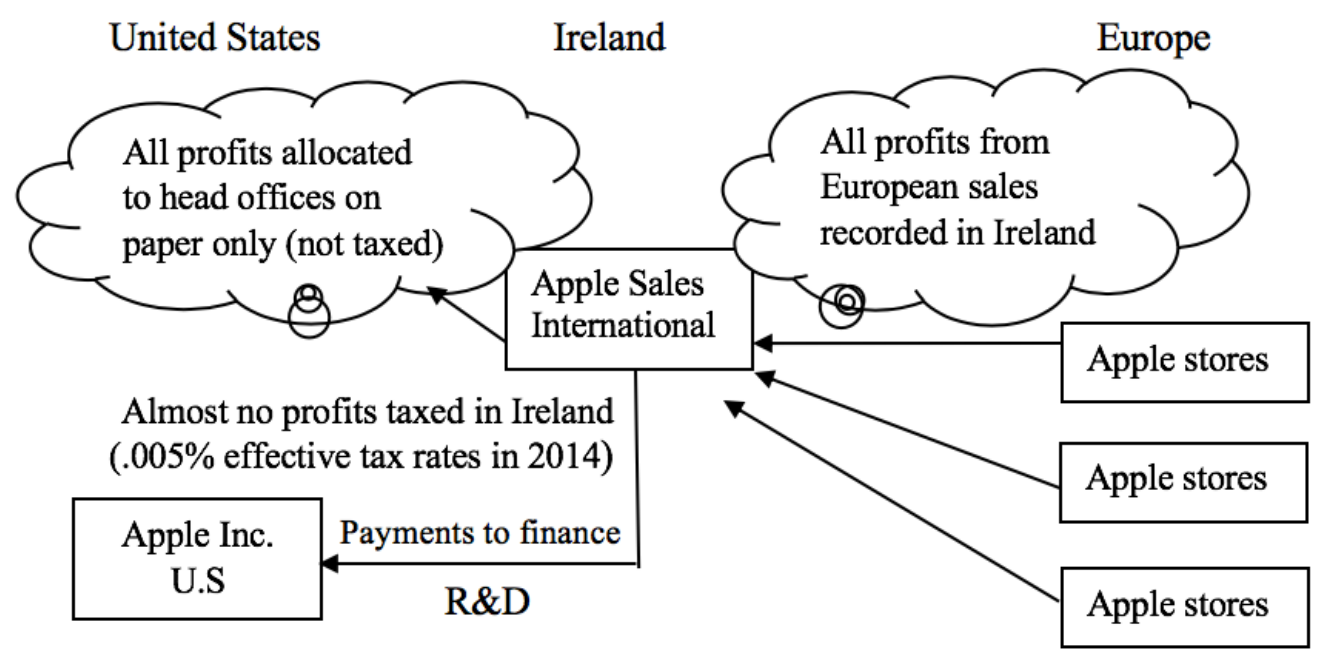

Figure 2. Ireland gave illegal preferential tax treatment to Apple Source: Adopted from Permanent Subcommittee on Investigations, May 2013. 


\section{Case 2: Starbucks}

Starbucks, a Seattle-based group is the second largest café chain globally. Starbucks paid only £8.6 million in corporate tax since its operation in the UK That is too small for a company with a market capitalization of $£ 40$ billion. It had generated about $£ 400$ million sales in 2011 in the UK but did not pay any tax (Geoghegan, 2012). This is unjustifiable when compared to McDonald's and Kentucky Fried Chicken, which paid over $£ 80$ million tax on $£ 3.6$ billion sales and $£ 36$ million tax on $£ 1.1$ billion sales respectively in the UK (Bergin, 2012).

The Netherlands tax authority granted Starbucks special tax rates, which prompted Starbucks to relocate its manufacturing entity, Starbucks Manufacturing to the Netherlands. Starbucks Manufacturing does not own the rights to coffee roasting knowhow but pays a royalty to a UK related company, Alki. However, Starbucks Manufacturing owned distributing rights. All Starbucks subsidiaries and outlets in Europe, the Middle East and Africa sourced their roasted coffee beans and other products from Starbucks Manufacturing, Netherlands. Starbuck Manufacturing bought coffee beans from a Starbucks Coffee Trading Company, based in Switzerland at an inflated price.

The European Commission (2015) has established that the corporate restructuring by Starbucks was to take advantage of the favourable tax rates. It was also established that the royalty paid does not reflect market value and the amount paid shifted a large portion of Starbucks Manufacturing taxable profits to Alki. In addition, Starbucks Manufacturing bought the coffee beans at an inflated price from Starbucks Coffee Trading Company, which further reduced the Starbucks Manufacturing tax base. However, Alki does pay any taxes in neither the UK nor the Netherlands. Further, Starbucks Coffee Trading Company, Switzerland merely acts as a purchasing agent with no added value (paper transaction only). The transfer pricing rules allow Starbucks Switzerland to charge for intra-group services. These arrangements allow Starbucks to create artificial expenses out of paper transactions between parent and subsidiaries, which enable Starbucks to shift income from a high tax to a low tax country, thus gaining tax advantage.

Starbucks' tax avoidance case illustrates an excellent example of how to create false expenses through paper transactions between a parent company and a subsidiary. 


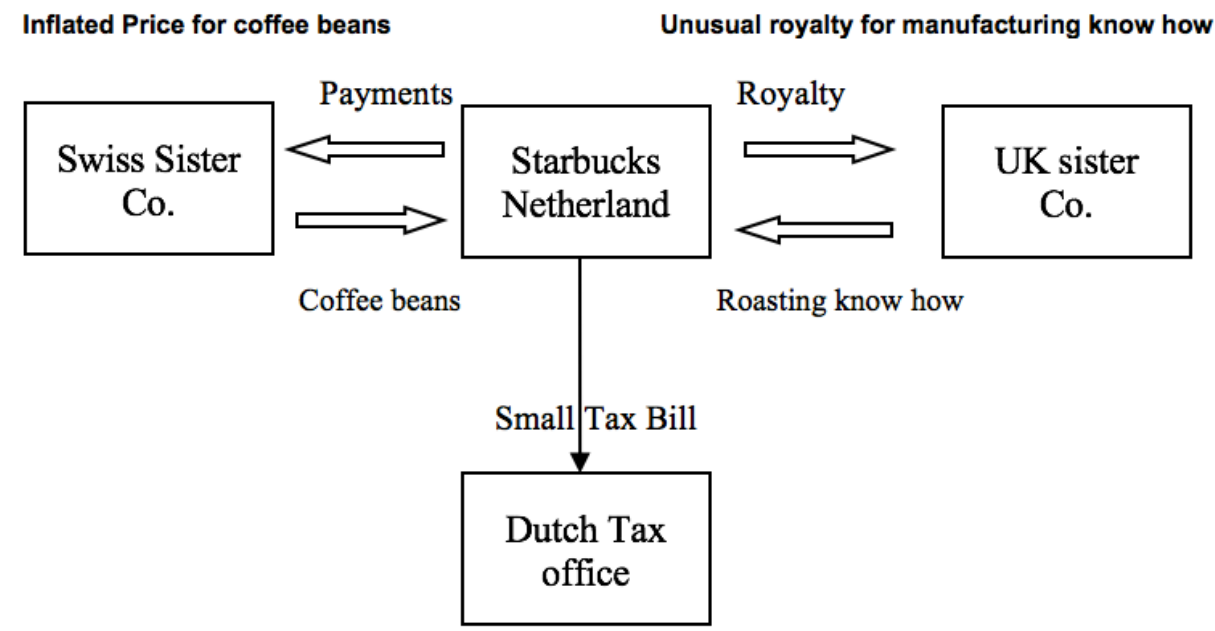

Figure 3. Starbucks Tax Avoidance Schemes Source: Guardian Graphic

\section{MALAYSIA AGGRESSIVE TAX PLANNING CASES}

The European Commission ruling revealed that Apple Inc. and Starbucks employed "artificial and complex schemes to create taxable income" and that these schemes did "not reflect real economic activity" (The European Commission, 2015; 2016). It was established that both companies were fully responsible for underpaid taxes. However, governments are still giving 'sweetheart deals' or overly generous tax benefits to attract foreign direct investments. Malaysia is in the same situation, where certain firms are granted special treatments in the form of tax incentives or tax exemptions. The Inland Revenue Board of Malaysia has detected various types of aggressive tax planning during tax audits and tax investigations. One of the common methods employed is shifting income from a high tax company to a low tax company or company enjoying tax incentives.

The cases presented were selected from the various tax plans detected through referrals from the field auditors and investigators. As these cases are not published in public domains, pseudo-names are used to protect their identities.

\section{Corporate Restructuring}

\section{Case 1: LH Group}

$\mathrm{LH}$ underwent an internal reorganization involving one of its subsidiaries, PLB, a listed company in the Bursa Malaysia. PLB owns a commercial complex and derived income from the rental of commercial shop lots. The exercise was conducted by the delisting of securities and distribution of cash proceeds to the shareholders from the disposal of shares through capital reduction. LYH then acquired all the assets and liabilities through a new company, New Co.

LH has granted stamp duty exemption on this transaction under Section 15A Stamps Duty Act 1949, and Real Property Gains Tax under Exemption Order 2011, Act 169 , and Real Property Gains Tax Act 1976. The offer price for the shares was $\$ 600$ million. The purchase was financed by a loan of $\$ 380$ million taken by NewCo., and the balance (treated as loan in the accounts of PLB) to paid by dividends to be issued by 
PLB. However, only $\$ 300$ million was paid for the transaction. The restructuring exercise is illustrated below:

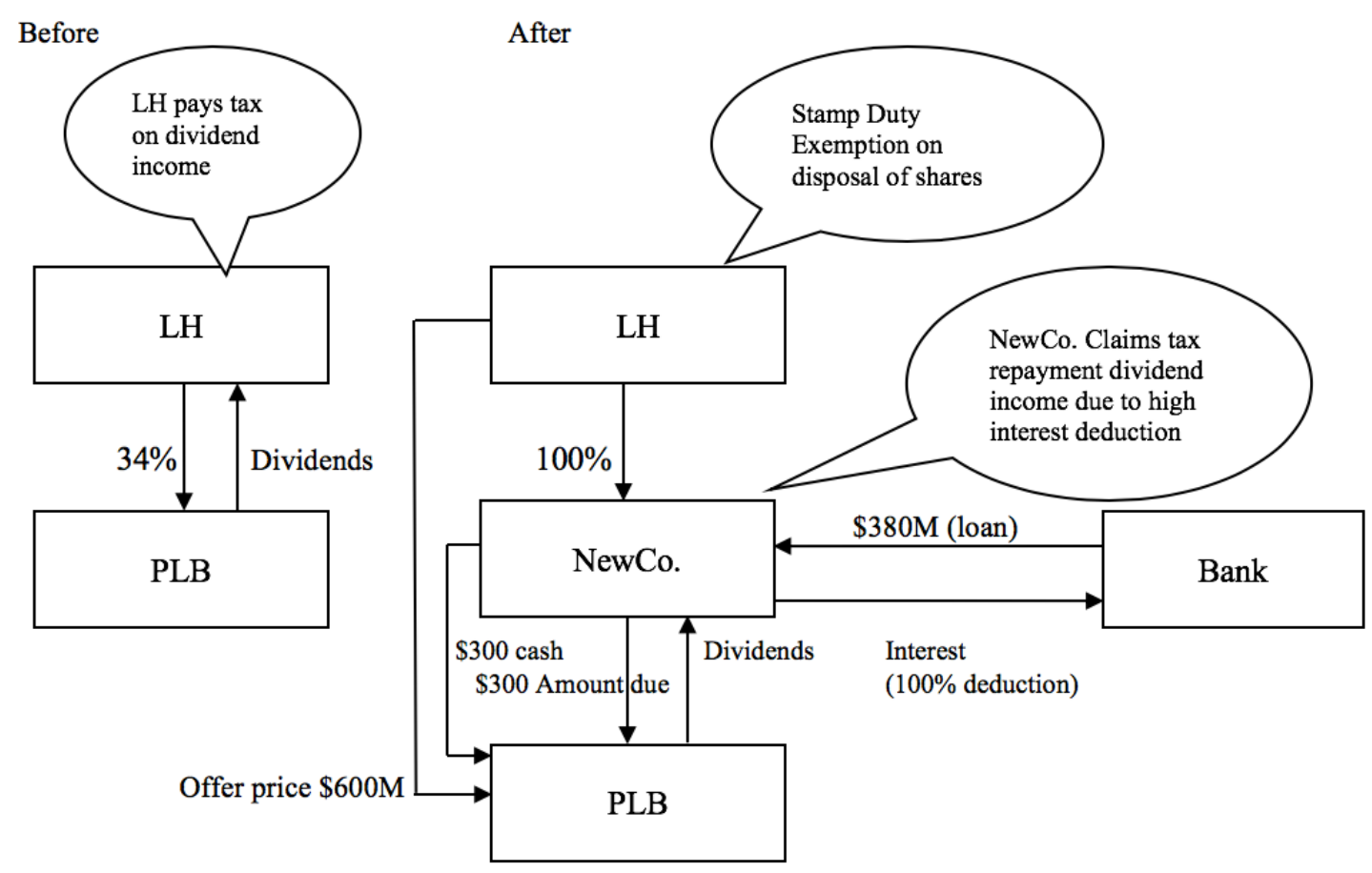

Figure 4. LYH restructuring exercise Source: IRB Data Management Records

\section{FINDINGS}

LH was a taxable entity before the restructuring exercise. After restructuring, the group becomes not only non-taxable but claimed tax repayment. The huge amount of interest deduction against dividend and rental income results in a tax repayment. The loan amount taken was not fully disbursed in the restructuring exercise, and the company tried to take advantage of the full deduction of interest payable, which is not wholly and inclusively deductible. The Revenue restricted the amount of interest deductible resulting in tax owing to the government. Secondly, $\mathrm{LH}$ takes advantage of the Exemption Orders of 2011 to restructure, but in reality, the business model does not change except the majority shareholders received a huge amount of monies received through capital reduction and repayment exercise which is not taxed. The assets transferred were only on paper and not registered under the NewCo.

\section{Case 2: Use of SPV to avoid paying Withholding Tax (Ensco-Gerudi case)}

The taxpayer is part of a multinational group specialized in providing offshore drilling services in the petroleum industry. The main taxpayer activity is the leasing of vessels. However, the taxpayer does not own any vessels but leased vessels from a Labuan group of company. The Labuan group also does not own any vessels but leased vessels from vessel-owning companies within the multinational group. The arrangement allows the taxpayer to escape paying withholding tax for the leasing of vessels (about RM500 million). 
This case was taken to the courts up to the Court of Appeals. The Revenue argued that if the taxpayer had paid the leasing payments directly to the vessel owners, it would trigger withholding tax payments. Further, the Labuan group had no staff, no bank account and management and control were carried out by the parent company. Even though the Labuan Company only exists on paper; the courts held that the Labuan entity was a legal entity where it furnished its tax return and paid its taxes. Furthermore, the taxpayer had the approval of the Finance Ministry to transact with the Labuan entity.

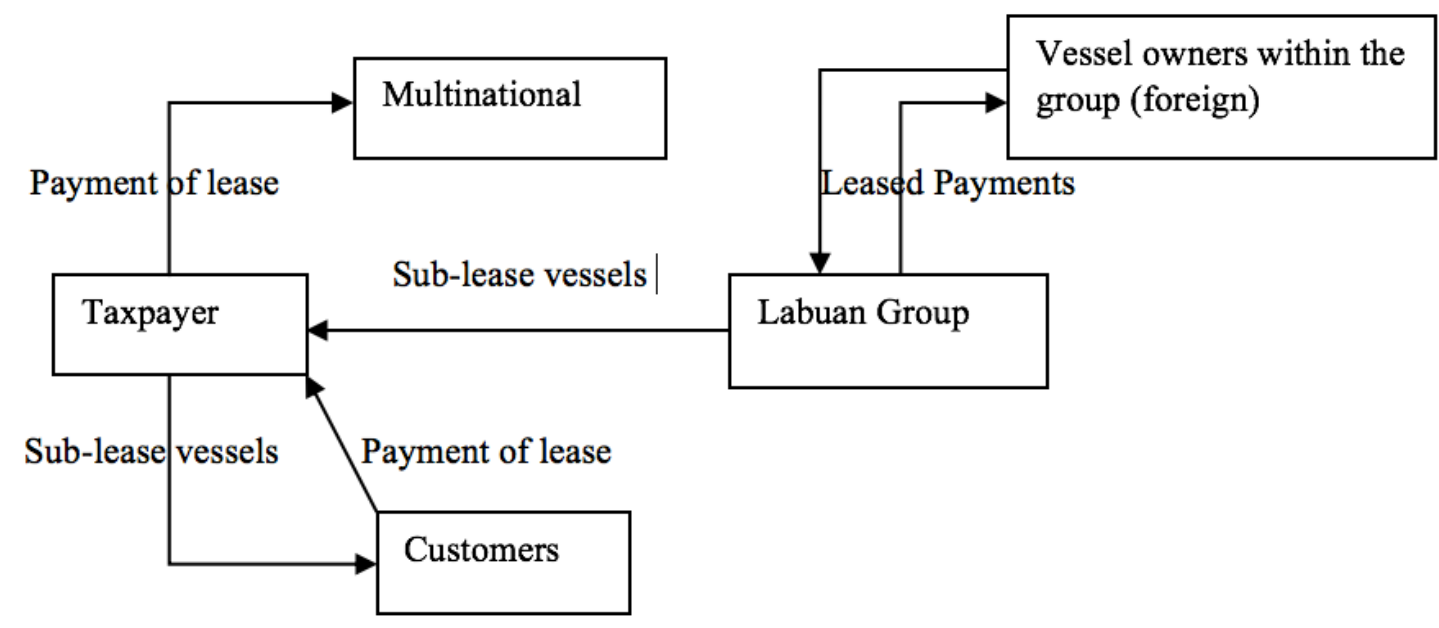

Figure 5. Ensco-Gerudi Case

The taxpayer has demonstrated that it has taken active steps to adhere to the Guidelines and its business and tax affairs were within the framework of Malaysian law. Thus, cannot be assumed as avoiding taxes. The decision of the High Court was upheld by the Court of Appeal.

\section{Case 3: Ibraco-Peremba Sdn Bhd vs Director General of Inland Revenue Board (DGIR)}

Ibraco-Peremba (hereby the taxpayer) was in the business of property development and profits arising from this activity is taxable as business income under the Income Tax Act. The taxpayer has found several land suitable for future development and intended to build shop-houses and a shopping complex. However, such a venture would attract income tax as profit derived is regarded as business income. The taxpayer went into a restructuring exercise following the advice of Arthur Andersen in their effort to minimize their tax exposure. The taxpayer formed a subsidiary, an investment holding company, to undertake the project. The taxpayer-funded the whole project. The shop-houses developed were leased for five years, and upon completion of the five years, as advised by the tax consultant, the taxpayer commenced a restructuring exercise. The taxpayer sold some shares of the subsidiary to a related company. Finally, the subsidiary and the related company were wound up.

The DGIR contended that the proceeds from the restructuring exercise are taxable as business income under the income tax act. The taxpayer was a property developer, and it acquired and developed land for resale through a special vehicle.

The subsidiary developed the land only on paper. The subsidiary does not have the expertise, resources and funds. The development was fully funded by the taxpayer. The 
profit derived from such activity is taxable as business income under the Income Tax Act. The taxpayer had sought the advice from a tax consultant and followed the advice.

Furthermore, the setting up of the subsidiary was merely to alter the incidence of tax and to cover the intention of the taxpayer to develop the land. The restructuring exercise undertaken creates a scenario where the resulting profit appears to be regarded as capital gains, which otherwise will be taxed as business profits. The structure proposed by AA was using a shell company is a sham, with no economic nor commercial purpose. The subsidiary has no expertise nor resources and funds to undertake the project. The proposed structure, when implemented, change the nature of income from business income to capital gains, taxable under the Real Property Gains Tax Act. In this case, after five years, the proceeds from disposal would not be taxable. The share transfer would be exempted from stamp duty as the transfer of shares between related companies is exempted under section $15 \mathrm{~A}$ of the Stamp Duty Act. The Revenue contended that the formation of the subsidiary and related company and the restructuring exercise was implemented for tax avoidance. Once they had accomplished their tasks, both entities had been voluntarily wound up by the taxpayer.

The case was taken to the courts up to the Court of Appeal. The Court of Appeal held that it was clear that the taxpayer had sought the advice of tax consultant to minimize tax liability. Further, there were also findings that the taxpayer executed the transactions following the advice of the tax consultant in enabling its original intention to sell the project. The courts highlighted that the onus is on the taxpayer to demonstrate that the arrangement is an accepted business practice in compliance with the tax law, and the tax savings were simply incidental. Having failed to do so, the courts held that the transactions or arrangement was premeditated to avoid paying tax and the fact that the transactions were executed using shell companies exposed the intention to alter the incidence of tax. The principle in W.T. Ramsay vs Inland Revenue Commissioner is applied where the courts looked the transaction as a whole.

\section{CONCLUSIONS}

This study is consistent with the full range of tax planning methodologies, which match the scope of Base Erosion Profit Shifting (BEPS), as described in the OECD BEPS Action Plan. The case studies manifest all the ingredients in tax planning, which includes profit shifting, relocation of headquarters, the strategic location of intangible assets and exploitation of debt management. It also includes cases of corporate restructuring, where holding companies transform from the public to private companies through capital reduction exercise. The restructuring exercise results in debt relocation and debt conversion (debt converted to equity) where interest deduction is being manipulated.

The Labuan case demonstrates the loopholes of the tax laws and treaty abuse and preferential tax rates. The creation of a shell company in Labuan with low tax rates and routing leasing payments through the Labuan entity enable the foreign company to escape paying withholding taxes. The courts recognized these tax structures as they are within the framework of the law. The Malaysian authorities need to address these loopholes when approving investments applications in Malaysia via Labuan. Sabin, CEO of the Inland Revenue Board of Malaysia, said: "Among the methods used by these aggressive taxpayers include mergers and acquisitions of companies and the manipulation of the Labuan Business Companies Act 1990" (Brohier, 2018).

The decision in the Ibraco-Peremba and Ensco-Gerudi cases indicates that the courts accept tax mitigation and the courts reinforce that taxpayer must be able to prove that the transaction or the arrangement involved are accepted business practice with economic and commercial sense. The resulting tax savings is simply incidental. 
Otherwise, the Revenue may invoke the tax avoidance provision to recover the tax deficiencies.

The paper concludes that corporations used complicated transactions or schemes to exploit preferential tax regimes and to manipulate loopholes between tax systems. These schemes facilitate them to avoid or reduce their tax exposure. While others may reduce their tax liabilities through shifting of profits via transfer pricing (intra-group transactions) and the relocation of debt, other enablers of tax avoidance include private banks, legal and investment consultants (Henry, 2012). The Enron case is an excellent example where the professional consultants colluded to structure complex arrangements to defray the authorities ("ENRON", 2003).

Malaysia has taken steps to coordinate her tax preferential tax regimes particular in granting tax incentives through the formation of the Incentives Coordination and Collaboration Office (ICCO) in 2017. The ICCO established under the Malaysian Investment Development Authority (MIDA), primarily is responsible for coordinating all investments incentives to ensure the effective and efficient use of tax incentives. The ICCO also provides advice and coordinate inter-agency visibility in their effort to moderate opportunities for rent-seeking and corruption. Malaysia is committed to fighting international tax avoidance, and the Inland Revenue Board has been entrusted with forming a special team consisting of experts from various enforcement agencies to address these issues (Ratna, 2017). Malaysia has officially joined the OECD Inclusive Framework (IF) on BEPS as Associate Members and is committed to implement and to adhere to the International Taxation standard in her effort to address tax planning especially involving aggressive tax planning.

\section{REFERENCES}

Arel-Bundock, V. (2017). The Unintended Consequences of Bilateralism: Treaty Shopping and International Tax Policy. International Organization, 71, 349-371.

Arukesamy, K. (2018). IRB to Adress Tax evasion loopholes. The Sun Daily, 07 February 2018. Available at: https://www.thesundaily.my/archive/irb-address-tax-evasion-loopholes-updatedYUARCH524403

Bergin, T. (2012). Special Report: How Starbucks Avoid UK Taxes. Online Reuters, 15 October 2012. Accessed 19 April 2018.

Brohier, M. (2018). IRB Cracking Down On Tax Evaders To Ensure Success Of Collection Target. https://www.imoney.my/articles/aggressive-tax-collection

Cobham, A. \& Jansky, P. (2018). Global Distribution of Revenue Loss from Corporate Tax Avoidance: Re-estimation and Country Results. Journal of International Development, 30, 206-232.

Drozdiak, N. \& Schechner, S. (2016). Apple Ordered by EU to Repay $\$ 14.5$ Billion in Irish Tax Breaks. The Wall Street Journal. Available at: http://www.wsj.com/articles/apple-received-145-billion-in-illegal-tax-benefits-from-ireland-1472551598

ENRON: The Joint Committee on Taxation's Investigative Report (2003). Committee of Finance. 108-117. Available at: https://www.finance.senate.gov/imo/media/doc/89349.pdf.

Geoghegan, B. (2012). UK Uncut Protests over Starbucks 'Tax Avoidance'. Online BBC, 8 December 2012. Available at: < http://www.bbc.com/news/uk-20650945> [Accessed 30 August 2018] record/8905597/file/8905599.pdf.

Hanlon, M. \& Heitzman, S. (2010). A review of tax research. Journal of Accounting and Economics, 50 (1-2), 127-178.

Hasseldine, J., Holland, K. \& Van der Rijt, P. (2012). Companies and taxes in the UK: Actors, actions, consequences and responses. eJournal of Tax Research, 10 (3). 532.

Henry, J. S. (2012). The price of offshore revisited: New estimates for missing global private wealth income inequality and lost taxes. Tax Justice Network, available at: www. 
taxjustice.net/cms/upload/pdf/Price_of_Offshore_Revisited_120722.pdf (accessed 26 July 2018).

Kasperkevic, J. (2016). Forget Panama: it is easier to hide your money in the US than almost anywhere. The Guardian, New York. Available at: https://www.theguardian.com/usnews/2016/apr/06/panama-papers-us-tax-havens-delaware.

Ksovreli, I. (2015). Aggressive Tax Planning - Challenge of the Digital Era (Schemes, Problems Caused and Remedies). Available online:lup.lub.lu.se/student-papers/

Leaked Documents Expose Global Companies' Secret Tax Deals in Luxembourg (2014). International Consortium of Investigative Journalists. Available from: https://www.icij.org/investigations/luxembourg-leaks/leaked-documents-expose-globalcompanies-secret-tax-deals-luxembourg/iPolitics (2014), Advance income tax rulings tipping off CRA to aggressive tax planning schemes: Ferguson

Lisowsky, P. (2010). Seeking shelter: Empirically modelling tax shelters using financial statement information. The Accounting Review, 85(5), 1693-1720.

Mauritius Economy 2018 (2018). CIA World Factbook. Available online: https://theodora.com/wfbcurrent/mauritius/mauritius_economy.html

Morgan, J. (2016). Corporation Tax as a Problem of MN C as Organizational Circuits: The Case for Unitary Taxation. The British Journal of Politics and International Relations 18: 463-81.

OECD (2017), BEPS Action 5 on Harmful Tax Practices - Terms of Reference and Methodology for the Conduct of the Peer Reviews of the Action 5 Transparency Framework, OECD/G20 Base Erosion and Profit Shifting Project, OECD, Paris.

Olbert, M. \& Spengel, C. (2017). International Taxation in the Digital Economy: Challenge Accepted?. World Tax Journal. February, 2017. 3-46

Ratna, I. (2017). The Malaysian Reserve: IRB to set up a special team to address tax avoidance issues. The Malaysian Reserve. Available at: https://themalaysianreserve.com/2017/07/26/irb-set-special-team-address-tax-avoidanceissues/

Swanson, A. (2016). How the U.S. became one of the world's biggest tax havens. Washington Post. Retrieved April 23, 2017. Available at: http://ticotimes.net/2016/04/05/u-s-one-worldsbiggest-tax-havens

The European Commission (2015). The Commission Decides Selective Tax Advantages for Fiat in Luxembourg and Starbucks in the Netherlands Are Illegal under EU State Aid Rules. The European Commission - Press Release. Brussels, October 21. Available online: http://europa.eu/rapid/press-release_IP-15-5880_en.htm (accessed on 27 December 2017)

The European Commission (2016). State Aid: Ireland Gave Illegal Tax Benefits to Apple Worth up to $€ 13$ billion. Press release. Brussels, August 30 . Available online: http://europa.eu/rapid/press-release_IP-16-2923_en. htm (accessed on 5 January 2018).

Turner, G. (2017). New estimates reveal the extent of tax avoidance by multinationals, Tax Justice Network. Available online: https://www.taxjustice.net /2017/03/22/new-estimates-taxavoidance-multinationals/

VanDenburgh, J. T. (2012). Closing International Loopholes: Changing the Corporate Tax Base to Effectively Combat Tax Avoidance, Valparaiso University Law Review, 47(1). 313-355. Available at: http://scholar.valpo.edu/vulr/vol47/iss1/8.

Vicentes, E. D. (2017). Can Blockchain Saved Offshore Banks?. ICO Services. https://medium.com/@icoservices/can-blockchain-save-offshore-banks-993ed84ebbd0.

Yang, J. G. S. \& Metallo, V. N. A. (2018). The Emerging International Taxation Problems. International Journal of Financial Studies, 6(1). 1-10.

Zolt, E. M (2016). Designing Effective Tax Incentives: Maximizing the Benefits and Minimizing the Costs. Proceeding of Singopore Management University. UCLA School of Law, Singapore. Available at: https://accountancy.smu.edu.sg/cet/system/files/cet/download/Designing 